\title{
Misregulation of maltose uptake in a glucose repression defective mutant of Saccharomyces cerevisiae leads to glucose poisoning
}

\author{
KarL-Dieter EnTIAN ${ }^{1}$ and Maria C. Loureiro-Dias ${ }^{2 *}$ \\ ${ }^{1}$ Institute for Microbiology, University of Frankfurt, Theodor-Stern-Kai 7, Haus 75AD-6000 Frankfurt/M., \\ Federal Republic of Germany \\ ${ }^{2}$ Laboratory of Microbiology, Gulbenkian Institute of Science, 2781 Oeiras, Portugal
}

(Received 17 October 1989; accepted 29 January 1990)

\begin{abstract}
In hex 2 mutants of Saccharomyces cerevisiae, which are defective in glucose repression of several enzymes, growth is inhibited if maltose is present in the medium. After adding $\left[{ }^{14} \mathrm{C}\right]$ maltose to cultures growing with ethanol, maltose metabolism was followed in both hex 2 mutant and wild-type cells. The amount of radioactivity incorporated was much higher in hex 2 than in wild-type cells. Most of the radioactivity in hex 2 cells was located in the low molecular mass fraction. Pulse-chase experiments showed that $2 \mathrm{~h}$ after addition of maltose, hex 2 cells hydrolysed maltose to glucose, which was partially excreted into the medium. ${ }^{31} \mathrm{P}-\mathrm{NMR}$ studies gave evidence that turnover of sugar phosphates was completely abolished in hex 2 cells after $2 \mathrm{~h}$ incubation with maltose. ${ }^{13} \mathrm{C}$-NMR spectiv confirmed these results: unlike those for the wild-type, no resonances corresponding to fermentation products (ethanol, glycerol) were found for hex 2 cells, whereas there were resonances corresponding to glucose. Although maltose is taken up by proton symport, the internal $\mathrm{pH}$ in the hex 2 mutant did not change markedly during the $5 \mathrm{~h}$ after adding maltose. The intracellular accumulation of glucose seems to explain the inhibition of growth by maltose, probably by means of osmotic damage and/or unspecific $\boldsymbol{O}$-glycosylation of proteins. Neither maltose permease nor maltase was over-expressed, and so these enzymes were not the cause of glucose accumulation. Hence, the coordination of maltose uptake, hydrolysis to glucose and glycolysis of glucose is not regulated simply by the specific activity of the catabolic enzymes involved. The results indicate that there is an unknown regulatory mechanism, under control of $\mathrm{HEX} 2$, which coordinates glycolytic flux and maltose uptake. Furthermore, the excretion of accumulated glucose into the medium gives clear evidence that at least one glucose carrier in $S$. cerevisiae acts passively and transports glucose in both directions.
\end{abstract}

\section{Introduction}

In Saccharomyces cerevisiae, glucose repression of enzymes necessary for the utilization of exogenously supplied sugars such as maltose, sucrose and galactose is under the control of several genes (for reviews see Entian, 1986; Gancedo \& Gancedo, 1986; Carlson, 1987). Mutations in the genes $H E X 1$ (HXK2), HEX2 and $C A T 80$ lead to non-repressible mutants (Zimmermann \& Scheel, 1977; Entian \& Zimmermann, 1980). Whereas $H E X 1$ is the structural gene for hexokinase isoenzyme PII (Entian, 1980a; Entian \& Mecke, 1982), HEX2 and $C A T 80$ are regulatory genes. Several experiments have given convincing evidence that hexokinase PII corresponds to the so-called 'recognition site' of glucose repression, giving a triggering signal which also requires the products of the HEX2 and CAT80 genes (Entian et al., 1985).

Besides the defect in glucose repression, hex 2 mutants show additional phenotypic effects. After growth on glucose, these mutants show increased hexokinase PII activity (Entian, 1981), indicating that hexokinase PII synthesis is regulated in coordination with repressible genes. In addition, hex 2 mutants are strongly inhibited by maltose (Entian, 1980 b). Maltose inhibitory effects can be observed $90 \mathrm{~min}$ after adding maltose to cells growing with ethanol or glucose as carbon source; after this period, fermentative activity decreases markedly, protein synthesis and growth stop and the cells are irreversibly damaged.

To understand the toxic effect of maltose, the activity of maltose permease, intracellular $\mathrm{pH}$ and the metabolic fate of $\left[{ }^{14} \mathrm{C}\right]$ maltose were studied in the wild-type and in hex2 mutants of $S$. cerevisiae. 


\section{Methods}

Strains. These were derived through a series of crosses from strains of the Department of Genetics of the University of Washington, Seattle, USA: SMC-1B (MATa his4 MAL2- $8^{\mathrm{c}} M A L 3$ SUC 3 CAT1-2d HEX2); SMC-1B/3 (MATa his4 MAL2-8c MAL3 SUC3 CAT1-2d hex2-3) (for gene symbols see Entian, 1980a).

Media and growth conditions. The major components of the culture media were $1 \%(\mathrm{w} / \mathrm{v})$ yeast extract (Difco) and $2 \%(\mathrm{w} / \mathrm{v})$ Bacto peptone (Difco). Carbon sources added were $3 \%(w / v)$ ethanol or $2 \%(w / v)$ sugar.

Growth conditions were as described by Zimmermann \& Scheel (1977).

Crude extracts. After labelling cells with $\left[{ }^{14} \mathrm{C}\right]$ maltose, crude extracts were prepared with glass beads (diameter $1 \mathrm{~mm}$, Braun-Melsungen). Portions $(5 \mathrm{ml}$ ) of cell suspension were filtered (pore diameter $0.8 \mu \mathrm{m}$; Millipore) and washed with ice-cold buffer $(0 \cdot 1 \mathrm{M}$-potassium phosphate, $\mathrm{pH}$ 6.5). The filters were transferred into $10 \mathrm{ml}$ tubes with forceps, so that the upper surface of the filter carrying cells faced inwards. Then $1.1 \mathrm{ml}$ buffer and $3 \mathrm{ml}$ glass beads were added and immediately shaken for $90 \mathrm{~s}$ on a laboratory tube shaker (Reax 2000; Heidolph). Microscopic examination indicated that all the cells were broken.

Protein in crude extracts was estimated by the method of Zamenhoff (1957) at $290 \mathrm{~nm}$, using bovine serum albumin as a standard.

Dry weight was estimated after filtering $10 \mathrm{ml}$ samples (pore diameter $0.8 \mu \mathrm{m}$; Millipore). Filters were dried for $30 \mathrm{~min}$ at $105^{\circ} \mathrm{C}$.

Radioactive labelling. This was done with $\left[\mathrm{U}-{ }^{14} \mathrm{C}\right]$ maltose $(3 \cdot 7-$ $10 \mathrm{kBq} \mathrm{ml}^{-1}$ ). Cells were grown on ethanol medium and maltose was added to a final concentration of $0.5 \%$.

For cell fractionation after radioactive labelling, cell debris was centrifuged for $10 \mathrm{~min}$ at $1000 \mathrm{~g}$. The sediment, corresponding to the cell wall fraction, was washed twice with buffer before measurement of radioactivity. The supernatant was mixed with $15 \%(\mathrm{w} / \mathrm{v})$ perchloric acid, giving a final concentration of $4 \%(\mathrm{w} / \mathrm{v})$, incubated for $10 \mathrm{~min}$ and finally centrifuged for $20 \mathrm{~min}$ at $6000 \mathrm{~g}$. The sediment, corresponding to the protein fraction, was washed twice with $5 \%(\mathrm{w} / \mathrm{v})$ perchloric acid. The remaining supernatant corresponded to the low molecular mass fraction.

For pulse-chase experiments, $50 \mathrm{ml}$ labelled cells were washed twice with $50 \mathrm{ml}$ cold medium, containing unlabelled maltose, and resuspended in $50 \mathrm{ml}$ (unlabelled) maltose medium at $30^{\circ} \mathrm{C}$.

Medium analysis. Media $(100 \mathrm{ml})$ were passed seven times through a cation-exchanger (Dowex); non-bound material was passed twice through an anion-exchanger (Dowex). Material which did not bind to either exchanger corresponded to the neutral fraction. Amino acids were eluted from the cation-exchanger with $8 \mathrm{ml} 10 \%(\mathrm{w} / \mathrm{v}) \mathrm{NH}_{4} \mathrm{OH}$. Organic acids were eluted from the anion-exchanger with $8 \mathrm{ml} 7 \mathrm{M}$ formic acid and phosphoric acids with $8 \mathrm{ml} 2 \mathrm{M}-\mathrm{HCl}$.

Thin-layer chromatography. Cellulose acetate plates $(0.2 \mathrm{~mm})$ were used. The neutral and the amino acid fraction were run with a solvent comprising $0.25 \mathrm{~g}$ EDTA, $20 \mathrm{ml} \mathrm{33 \% (w/v)} \mathrm{NH}_{4} \mathrm{OH}, 190 \mathrm{ml} \mathrm{H}_{2} \mathrm{O}$, $70 \mathrm{ml}$ l-propanol, $15 \mathrm{ml}$ 2-propanol, $15 \mathrm{ml} \mathrm{l-butanol} \mathrm{and} 500 \mathrm{ml}$ butyric acid. For organic acids a mixture of $100 \mathrm{ml}$ ethyl acetate, $20 \mathrm{ml}$ formic acid and $30 \mathrm{ml} \mathrm{H}_{2} \mathrm{O}$ was used. All chromatographs were run in one dimension only. After the first run, amino acids and neutral compounds were dried overnight, before the second run. Radioactivity was estimated using a thin-layer scanner.

Maltose permease activity. This was estimated by two independent methods (Loureiro-Dias \& Peinado, 1984).

(a) To determine the initial transport rate of $\left[{ }^{14} \mathrm{C}\right]$ maltose, cells were harvested by centrifugation, washed twice with $\mathrm{H}_{2} \mathrm{O}$ at $4{ }^{\circ} \mathrm{C}$ and resuspended to a final concentration of about $100 \mathrm{mg}$ dry weight $\mathrm{ml}^{-1}$. For the maltose transport assay, $1 \mathrm{mg}$ of cells (dry weight) were incubated for $10 \mathrm{~s}$ at $25^{\circ} \mathrm{C}$ with $10 \mathrm{mM}-\left[\mathrm{U}-{ }^{14} \mathrm{C}\right]$ maltose (about $10 \mathrm{GBq}$ $\mathrm{mol}^{-1}$ ) in $50 \mu \mathrm{l} 40 \mathrm{mM}$-Tris/citrate buffer, $\mathrm{pH} 5 \cdot 0$. After $10 \mathrm{~s}$ incubation, $5 \mathrm{ml}$ of ice-cold $\mathrm{H}_{2} \mathrm{O}$ was added and the cells were immediately filtered through Whatman $2.5 \mathrm{GF} / \mathrm{C}$ membranes and washed with $5 \mathrm{ml}$ ice-cold $\mathrm{H}_{2} \mathrm{O}$. Radioactivity in the filters was measured in a liquid scintillation counter.

(b) $\mathrm{H}^{+}$uptake coupled to initial transport of maltose was measured in $4 \mathrm{ml}$ of a cell suspension ( $50 \mathrm{mg}$ dry weight) in $\mathrm{H}_{2} \mathrm{O}$, adjusted to $\mathrm{pH} 5 \cdot 0$ in a water-jacketed vessel, monitored with a combined $\mathrm{pH}$ electrode and a pH meter (PHM 62, Radiometer). The $\mathrm{pH}$ was recorded and the addition of $10 \mathrm{~mm}$-maltose initiated the uptake of $\mathrm{H}^{+}$, observed through the alkalinization of the suspension medium. The rate of $\mathrm{H}^{+}$ uptake was calculated from the slope of the initial part of the curve, using $10 \mathrm{~mm}-\mathrm{HCl}$ to calibrate.

Intracellular $p H$. This was calculated (a) from the distribution of $\left[{ }^{3} \mathrm{H}\right]$ propionic acid (Rottenberg, 1979) and $(b)$ by ${ }^{31} \mathrm{P}-\mathrm{NMR}$ studies (Gillies et al., 1982).

(a) In the first method, the calculation was based on the equation

$$
\left[\mathrm{H}^{+}\right]_{\text {in }}=\frac{1}{\frac{\mathrm{C}_{\text {in }}}{\mathrm{C}_{\text {out }}}\left(\frac{1}{\left[\mathrm{H}^{+}\right]_{\text {out }}}+\frac{1}{k_{\mathrm{d}}}\right)-\frac{1}{k_{\mathrm{d}}}}
$$

where $\mathrm{C}$ refers to total concentration and $k_{\mathrm{d}}$ to the dissociation constant of the acid. After adding maltose, $20 \mathrm{ml}$ samples were removed from both cultures and incubated with $0.4 \mathrm{MBq}\left[1{ }^{-3} \mathrm{H}\right]$ propionic acid $(1 \mu \mathrm{M})$. At the time intervals indicated, $2 \mathrm{ml}$ of each culture was filtered as described above, the cells were washed with $5 \mathrm{ml}$ ice-cold $\mathrm{H}_{2} \mathrm{O}$ and radioactivity associated with the filters was counted. To calculate $\mathrm{C}_{\text {out }}$, $0.5 \mathrm{ml}$ samples were centrifuged and the radioactivity in $20 \mu \mathrm{l}$ of supernatant was measured. To calculate $C_{i n}$, internal volume was determined as described by Rottenberg (1979), using ${ }^{3} \mathrm{H}_{2} \mathrm{O}$ to define total volume and $\left[{ }^{14} \mathrm{C}\right]$ methoxyinulin to define external volume. From several measurements for both strains, during maltose incubation, a mean value for internal volume of $1.25 \mu \mathrm{l}(\mathrm{mg} \text { dry weight })^{-1}$ was calculated.

(b) Alternatively, the intracellular $\mathrm{pH}$ was calculated from ${ }^{31} \mathrm{P}-\mathrm{NMR}$ spectra (see below), from the chemical shifts of the orthophosphate resonance. For the calibration of $\mathrm{pH}$ values, titration plots of the chemical shifts were prepared using cell-free extracts of yeast cells.

NMR spectra. ${ }^{13} \mathrm{C}$-NMR and ${ }^{31} \mathrm{P}$-NMR spectra were acquired using a Bruker CXP 300 spectrometer. Cells were harvested $2 \mathrm{~h}$ after adding maltose $(2 \%, w / v)$ to cultures of strains grown on ethanol. Harvesting conditions were as described for determining maltose permease activity. For each experiment, $200 \mathrm{mg}$ of cells (dry weight) were resuspended in $4 \mathrm{ml} 25 \mathrm{~mm}$-Tris/citrate buffer, pH 7.5. Deuterium oxide $(100 \mu \mathrm{l})$ was added to provide a lock signal. An NMR tube $(10 \mathrm{~mm})$ provided with a simple flow apparatus (Santos \& Turner, 1986) was used. ${ }^{13} \mathrm{C}$-NMR spectra were obtained with continuous broad-band proton decoupling using $40^{\circ}$ pulses with a repetition time of $0.5 \mathrm{~s}$ at $75.47 \mathrm{MHz} ; 1000$ scans were accumulated for each ${ }^{13} \mathrm{C}-\mathrm{NMR}$ spectrum. The temperature of the sample was about $25^{\circ} \mathrm{C}$. ${ }^{31} \mathrm{P}-\mathrm{NMR}$ spectra were recorded at $121.5 \mathrm{MHz}$ using $45^{\circ}$ pulses with a repetition time of $0.5 \mathrm{~s} ; 400$ scans were accumulated and the temperature was about $19{ }^{\circ} \mathrm{C}$. Chemical shifts were referenced with respect to $85 \%$ $\mathrm{H}_{3} \mathrm{PO}_{4}$ contained in a capillary tube.

\section{Results}

The metabolism of $\left[{ }^{14} \mathrm{C}\right]$ maltose was followed after adding maltose to hex 2 and wild-type cells growing exponentially with ethanol as carbon source. The 


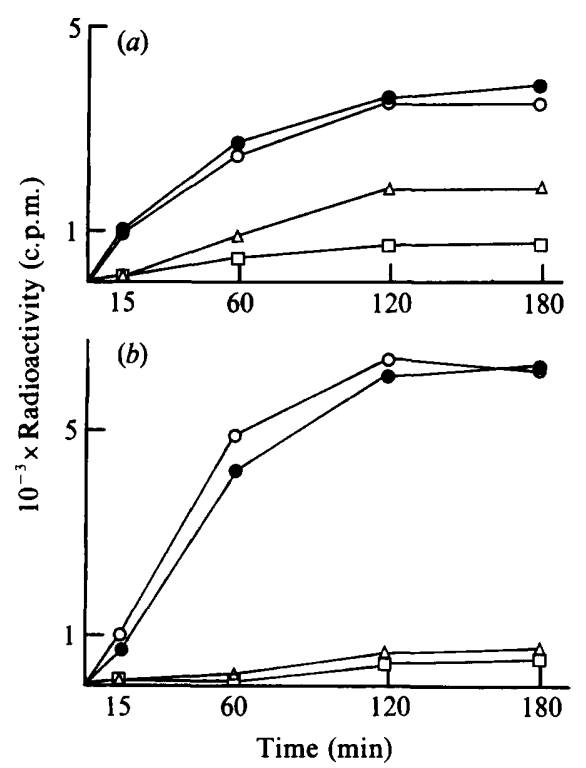

Fig. 1. Cell fractionation at different times after addition of $\left[{ }^{14} \mathrm{C}\right]$ maltose to $(a)$ wild-type and $(b)$ hex 2 celis growing with ethanol as carbon source. $\bullet$, Total radioactivity incorporated into the cells; $\square$, radioactivity in the cell debris fraction; $\Delta$, sum of the radioactivity in the cell debris and protein fractions; and $O$, sum of the radioactivity in the cell debris, protein and small molecule fractions.

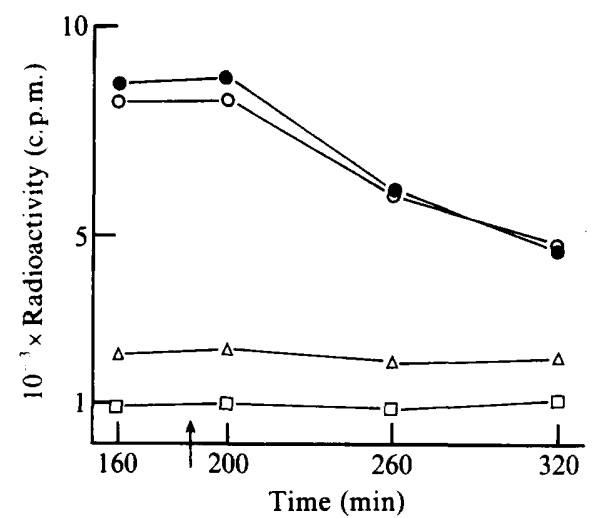

Fig. 2. Pulse-chase experiment with hex 2 cells. Cells were preincubated for $3 \mathrm{~h}$ with $\left[{ }^{14} \mathrm{C}\right]$ maltose and then transferred (arrow) to non-labelled medium. $\bullet$, Total radioactivity incorporated into the cells; $\square$, radioactivity in the cell debris fraction; $\triangle$, sum of the radioactivity in the cell debris and protein fractions; $O$, sum of the radioactivity in the cell debris, protein and small molecule fractions.

Table 1. Distribution of radioactivity in different medium fractions after transfer of hex 2 cells from $\left[{ }^{14} \mathrm{C}\right]$ maltoselabelled to non-labelled maltose medium

\begin{tabular}{ccccc}
\hline \hline \multirow{2}{*}{$\begin{array}{c}\text { Time } \\
\text { after } \\
\text { transfer } \\
\text { (min) }\end{array}$} & $\begin{array}{c}\text { Amino acid } \\
\text { fraction }\end{array}$ & $\begin{array}{c}\text { Organic acid } \\
\text { fraction }\end{array}$ & $\begin{array}{c}\text { Organic phosphate } \\
\text { fraction }\end{array}$ & $\begin{array}{c}\text { Neutral } \\
\text { fraction }\end{array}$ \\
\hline 20 & 40 & 29 & 19 & 970 \\
150 & 47 & 38 & 22 & 1280 \\
\hline \hline
\end{tabular}

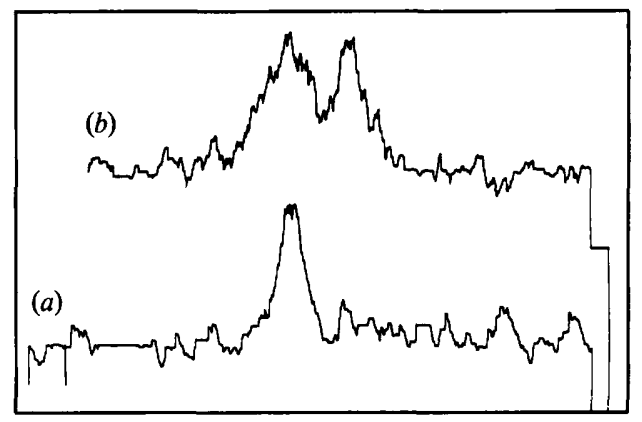

Fig. 3. Radioactivity detected after thin-layer chromatography of the neutral fraction, (a) $20 \mathrm{~min}$ and (b) $120 \mathrm{~min}$ after transfer of hex 2 cells from $\left[{ }^{14} \mathrm{C}\right]$ maltose-labelled to non-labelled maltose medium. Reference sugars identified the peaks as glucose and maltose.

biomass in both cultures was about $1 \mathrm{mg}$ dry weight $\mathrm{ml}^{-1}$. During the first $15 \mathrm{~min}$, the amount of maltose incorporated was the same for both strains. After $1 \mathrm{~h}$ the amount of incorporated radioactivity in hex 2 cells was twice that in the wild-type. At 2 and $3 \mathrm{~h}$ after maltose addition, when toxic effects occurred in hex 2 cells, the amount of radioactivity incorporated was still much higher than in the wild-type. Cell fractionations at various times showed that this difference applied mainly to the low molecular mass fraction. In the protein and cell wall fractions, there was actually less radioactivity incorporated in hex 2 than in wild-type cells (Fig. 1). Hence, a substance of low molecular mass seemed to be responsible for maltose toxicity.

In order to follow the metabolism of the low molecular mass fraction, hex 2 cells were transferred to nonradioactive maltose medium after $3 \mathrm{~h}$ incubation with $\left[{ }^{14} \mathrm{C}\right]$ maltose. Although radioactivity in the low molecular mass fraction decreased within $2 \mathrm{~h}$, there was no corresponding increase of radioactivity within the other cell fractions, such as protein and cell wall (Fig. 2). This indicated that biosynthetic activity was drastically reduced in hex 2 cells. Unexpectedly, radioactivity increased in the medium $(6900$ c.p.m. $20 \mathrm{~min}$ after transfer; 8930 c.p.m. 150 min after transfer), indicating either cell lysis or secretion of radioactivity. Accordingly, the medium was analysed further, and all the radioactivity was found to be associated with the neutral fraction (Table 1). Hence, a general leakiness of cells could be excluded, a likely explanation of these results being excretion of a sugar, possibly glucose, from hex 2 cells. Thin-layer chromatography gave a single peak of radioactivity immediately after transfer of the yeast cells to non-labelled maltose medium, whereas two peaks were detected $120 \mathrm{~min}$ after transfer (Fig. 3). These two peaks co-migrated with maltose and glucose used as standards. The radioactivity detected immediately after transfer clearly corresponded to radioactive maltose not 


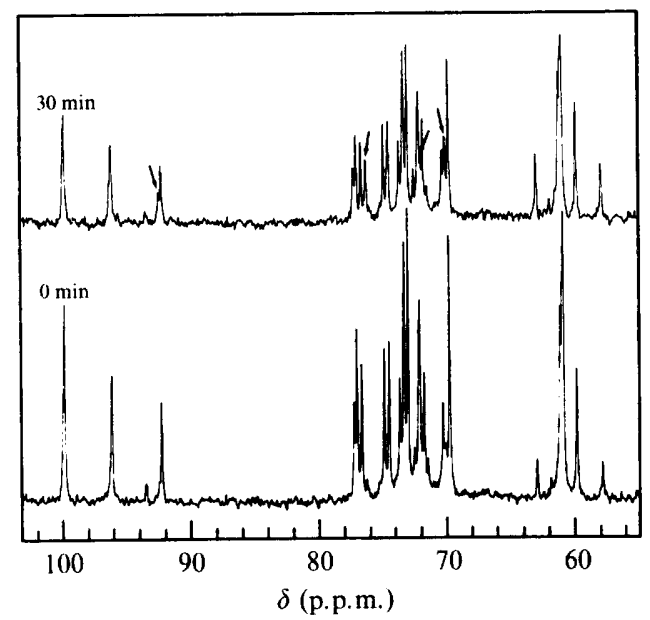

Fig. $4 .{ }^{13} \mathrm{C}$-NMR spectra of hex 2 cells incubated for $2 \mathrm{~h}$ with maltose,

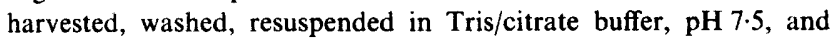
pulsed with $100 \mathrm{~mm}$-maltose. The four resonances indicated by the arrows $(92.37,76.14,71.83$ and 69.97 p.p.m.) $30 \mathrm{~min}$ after the maltose pulse correspond to glucose as confirmed by the addition of authentic glucose.

removed completely by the two washings. Hence, the radioactive material released from the cells must have been solely glucose. These results were confirmed by the natural abundance ${ }^{13} \mathrm{C}$-NMR spectra of suspensions of ethanol grown cells that were incubated for $2 \mathrm{~h}$ with maltose and then harvested as described in Methods. A pulse of $100 \mathrm{mM}$-maltose was given to these suspensions and the NMR spectra were obtained after $30 \mathrm{~min}$. Whilst in the wild-type strain, resonances corresponding to fermentation products (ethanol, glycerol) were found (data not shown), in the hex 2 mutant only resonances corresponding to glucose $(92.37,76 \cdot 14,71.83$ and 69.97 p.p.m.) were apparent (Fig. 4). The identity of the glucose resonances was confirmed by the addition of authentic glucose. These results indicated that glycolysis was strongly reduet in hex 2 cells. A subsequent experiment supported this finding (Fig. 5). Cells were incubated with maltose for $2 \mathrm{~h}$, washed twice, then resuspended in Tris/citrate buffer, $\mathrm{pH} \mathrm{7.5,} \mathrm{without}$ maltose, and harvested after about $30 \mathrm{~min}$. Resonance assignments were taken from the literature (Navon et al., 1979; Gage et al., 1984). As a result of continuing metabolism, no sugar phosphates were detected in wildtype cells. The resonances corresponding to middle and terminal phosphate of polyphosphate were strong in wild-type cells, but significantly less intense in hex 2 cells. Most remarkable, in the hex 2 mutant the resonance corresponding to sugar phosphates was still very pronounced (Fig. 5). There are two alternative explanations for this finding: (i) glycolysis was strongly reduced in hex 2 cells, or (ii) the high intracellular glucose accumulation provided sufficient substrate for phosphorylation

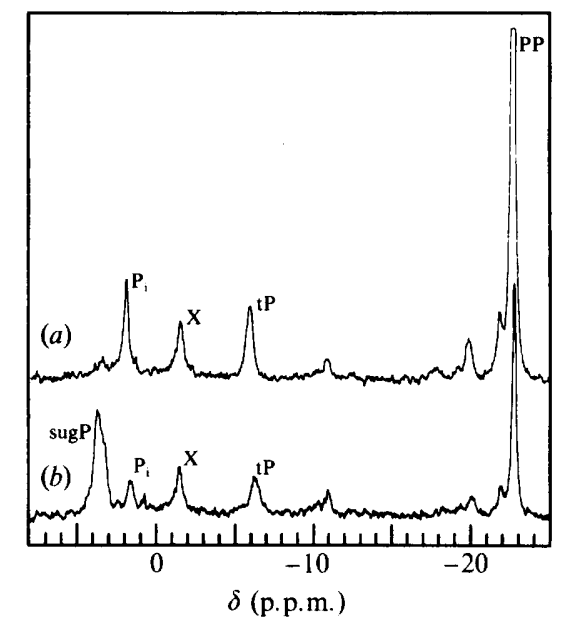

Fig. $5 .{ }^{31} \mathrm{P}-\mathrm{NMR}$ spectra of $(a)$ wild-type and $(b)$ hex 2 cells incubated for $2 \mathrm{~h}$ with maltose, harvested and resuspended in Tris/citrate buffer, $\mathrm{pH}$ 7.5. Each spectrum is the sum of 400 scans. $P_{i}$, inorganic phosphate; PP, middle phosphate of polyphosphate; tP, terminal phosphate of polyphosphate; sugP, sugar phosphate; $\mathrm{X}$, phosphomannan.

during the harvesting period. However, the absence of the glucose resonance at time 0 in the ${ }^{13} \mathrm{C}$-NMR spectra under similar experimental conditions (Fig. 4) supports the conclusion of a strongly reduced glycolysis. All other ${ }^{31} \mathrm{P}-\mathrm{NMR}$ resonances were of similar intensity in wildtype and hex 2 mutant cells.

All these findings clearly showed that adding maltose to hex 2 cells results in breakdown of glycolysis and metabolic paralysis. All the observed effects seem to result from the huge intracellular glucose accumulation which is the consequence of uncontrolled maltose hydrolysis, hence exceeding the glycolytic capacity.

Since our results indicated misregulated maltose uptake in hex 2 cells, the activity of maltose permease was estimated. Accordingly, the initial rate of uptake of $\left[{ }^{14} \mathrm{C}\right]$ maltose was measured and, since maltose is transported in $S$. cerevisiae by proton symport (Serrano, 1977) also by measuring initial proton uptake. The results obtained with both techniques were consistent. After growth with ethanol as carbon source, maltose permease activity was low in both the wild-type and the hex 2 mutant. The induction of maltose permease after maltose addition was similar for the first $2 \mathrm{~h}$ in both strains. Thereafter, maltose permease activity decreased in hex 2 cells (Fig. 6). Hence, the toxic effects also affected maltose permease. The decrease in maltose permease activity may reflect the half-life of the permease, as de novo protein synthesis is arrested in hex 2 cells. Unexpectedly, the specific activity of maltose permease never exceeded that of the wild-type. This is also true for maltase activity (Entian, $1980 b$ ). Hence, the coordination between maltose uptake, maltose hydro- 


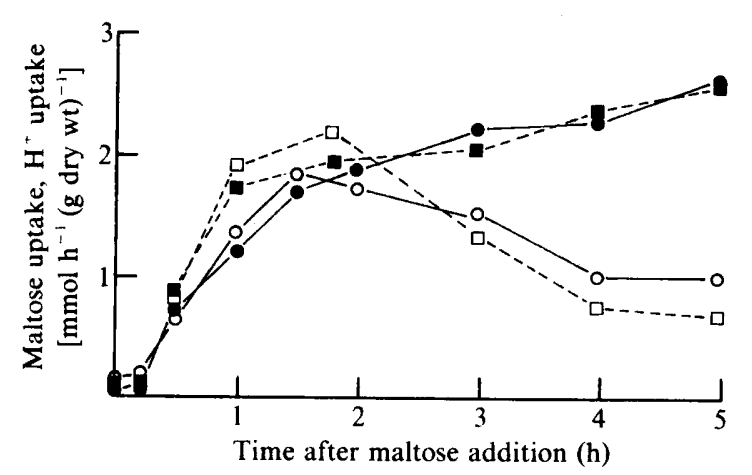

Fig. 6. Maltose permease activities at different times after addition of maltose to wild-type $(\bullet, \square)$ and hex $2(O, \square)$ cells, growing with ethanol as carbon source. Maltose permease activity was calculated from the initial transport rate of $\left[{ }^{14} \mathrm{C}\right]$ maltose (continuous lines) and from initial $\mathrm{H}^{+}$uptake (broken lines).

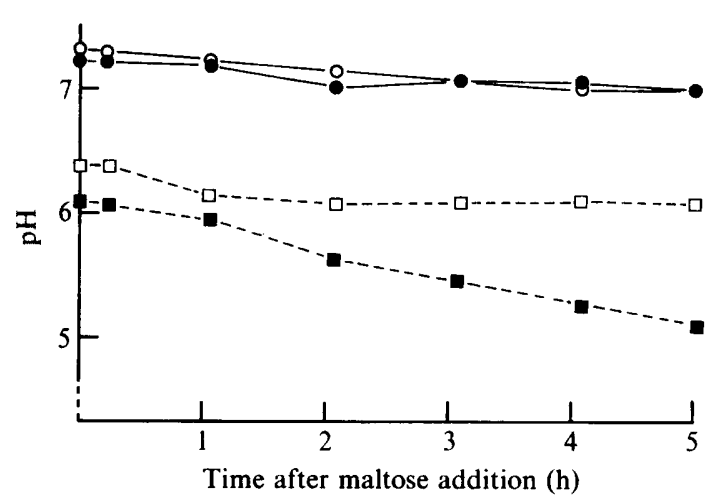

Fig. 7. Internal (continuous lines) and external (broken lines) $\mathrm{pH}$ in wild-type $(\bullet, \square)$ and hex 2 mutant $(O, \square)$ cells after addition of maltose to cells growing with ethanol.

lysis and glycolysis of liberated glucose cannot be regulated by the amount of the catabolic enzymes involved. These results indicate additional regulation of maltose permease.

To sum up, glucose accumulation is the main reason for maltose toxicity in hex 2 cells. As maltose is transported by proton symport, an alternative possibility might have been intracellular acidification as a result of an inefficient ATPase proton pump in the plasma membrane. However, measurement of the intracellular $\mathrm{pH}$ after maltose addition showed no difference between the wild-type and the hex 2 mutant (Fig. 7); the extracellular $\mathrm{pH}$ in suspensions of the wild-type cells fell, while that of the hex 2 cells remained unchanged, as they had much less metabolic activity (Fig. 7). These results were confirmed by the ${ }^{31} \mathrm{P}-\mathrm{NMR}$ studies. From the chemical shift of inorganic phosphate (Fig. 5) an internal $\mathrm{pH}$ of 6.87 was calculated for wild-type cells, and of 6.64 for hex 2 cells. Hence, glucose accumulation seems the only significant difference between hex 2 and wild-type cells $2 \mathrm{~h}$ after maltose addition.

\section{Discussion}

In hex 2 mutants of $S$. cerevisiae, glucose repression of many enzymes is affected, such as disaccharide-utilizing enzymes (invertase and maltase), respiratory enzymes, enzymes of the tricarboxylic acid cycle (Entian \& Zimmermann, 1980) and enzymes involved in porphyrin biosynthesis (Entian et al., 1985). Further, hexokinase PII activity is increased after growth on glucose (Entian, 1981). In principle, all these effects can be explained as an increased synthesis of the respective enzyme on glucose medium. Cloning and sequencing of the $H E X 2$ gene has suggested that it may encode a regulatory protein affecting transcription of glucose-repressible genes and hexokinase PII (Niederacher \& Entian, 1985; Entian et al., 1987). Hence, all the properties observed can be explained in terms of increased transcription, when the $H E X 2$ protein is not present in the cell. Maltose inhibition occurs as an additional phenotype in hex 2 mutants. The accumulation of glucose, observed $90 \mathrm{~min}$ after maltose addition, seems to explain maltose toxicity in hex 2 mutants. Surprisingly, no differences in specific activity of maltose permease and maltase could be observed between the wild-type and hex 2 mutant within the time interval of the occurrence of toxic effects of maltose. This indicates that the enzymes necessary for glucose accumulation are not over-expressed in hex2 cells. Hence, there must be an additional regulatory mechanism, so far unknown, which coordinates maltose metabolism and glycolytic capacity. Perhaps only maltose permease is subject to this regulation. Mutational analysis has shown that at least seven genes are involved in maltose uptake in S. cerevisiae (Zimmermann et al., 1973) and it may be that one or more of these genes is/are also under control of HEX2. However, this hypothesis remains speculative, as the nature of these regulatory genes is unclear and a direct action of the HEX2 protein on maltose permease cannot be excluded. Alternatively, an allosteric low molecular mass metabolic effector may control maltose permease activity. This, however, seems unlikely, as all other hex 2 effects are known to act at the transcriptional level.

The finding that intracellular $\mathrm{pH}$ remained unchanged, for at least $5 \mathrm{~h}$ after adding maltose to hex 2 cells, showed that the ATPase proton pump still remained coordinated with maltose- $\mathrm{H}^{+}$symport and that ATP was still available. This was consistent with the ATP concentrations being unchanged even $5 \mathrm{~h}$ after addition of maltose to hex 2 cells (Entian, 1980 b). Hence, the reduced glycolytic flux and respiratory activity were able to provide sufficient energy, so that depletion of energy can be excluded as a reason for maltose inhibition.

It is worth pointing out that hex 2 mutants liberate into 
the miedium the glucose obtained by maltose hydrolysis. This proves that at least one glucose carrier is passive in $S$. cerevisiae, transporting glucose in both directions.

The findings reported in the present paper support the idea that all the toxic effects of maltose can be explained by the huge accumulation of glucose observed in hex 2 mutants. There is a marked association between glucose accumulation and the inhibitory effects. Precisely when glucose accumulates, growth stops, fermentative activity decreases, maltase induction, as a criterion of de novo protein synthesis, is arrested and maltose permease activity decreases (Entian, 1980b). Two mechanisms may underly this inhibition. First, assuming that intracellular membranes are impermeable to glucose, the high cytoplasmic concentration (up to $0.3 \mathrm{M}$ ) of glucose may cause severe osmotic disorder, especially between cytoplasm and organelles. An unspecific lysis of cells can be excluded because no efflux of other metabolites was found. Secondly, acyclic glucose contains a free aldehyde group, and non-specific $O$-glycosylation by Schiff base formation with amino groups of proteins and DNA may occur, severely affecting the function of these molecules. This is observed, for example, in men suffering from diabetes mellitus (Cerami et al., 1987). Both mechanisms could operate. The osmotic damage may be responsible for the immediate response $90 \mathrm{~min}$ after maltose addition, whereas non-specific $O$-glycosylation may explain the increasingly irreversible toxicity observed after several hours.

We thank Dr H. Santos, from the Centro de Tecnologia Química e Biológica, Oeiras, Portugal, for her excellent support in performing the NMR experiments, Professor D. Mecke for many stimulating discussions and suggestions, and Dr J. A. Barnett for his critical reading of the manuscript. This work was supported by the Deutsche Forschungsgemeinschaft.

\section{References}

CARLSON, M. (1987). Regulation of sugar utilization in Saccharomyces cerevisiae species. Journal of Bacteriology 169, 4873-4877.

Cerami, A., Vlassara, H. \& Brownlee, M. (1987). Glucose und altern. Spektrum der Wissenschaft 7, 44-51.

ENTIAN, K.-D. $(1980 a)$. Genetic and biochemical evidence for hexokinase PII as a key enzyme involved in carbon catabolite repression in yeast. Molecular and General Genetics 178, 633-637.

ENTIAN, K.-D. (1980b). A defect in carbon catabolite repression associated with uncontrollable and excessive maltose uptake. Molecular and General Genetics 179, 169-175.
ENTIAN, K.-D. (1981). A carbon catabolite repression mutant of Saccharomyces cerevisiae with elevated hexokinase activity: evidence for a regulatory control of hexokinase PII synthesis. Molecular and General Genetics 184, 278-282.

ENTIAN, K.-D. (1986). Glucose repression: a complex regulatory system in yeast. Microbiological Sciences 3, 366-371.

Entian, K.-D. \& MeCKE, D. (1982). Genetic evidence for a role of hexokinase isoenzyme PII in carbon catabolite repression in Saccharomyces cerevisiae. Journal of Biological Chemistry 257, 870874.

ENTIAN, K.-D. \& ZimmermanN, F. K. (1980). Glycolytic enzymes and intermediates in carbon catabolite repression mutants of Saccharomyces cerevisiae. Molecular and General Genetics 177, 345-350.

Entian, K.-D., Hilberg, F., OPITZ, H. \& MeCKe, D. (1985). Cloning of hexokinase structural genes from Saccharomyces cerevisiae mutants with regulatory mutations responsible for glucose repression. Molecular and Cellular Biology 5, 3035-3040.

Entian, K.-D., Rose, M., Albig, W., Schuller, H.-J., Niederacher, D., GraAcK, H.-R., Hassler, S. \& Dussling, G. (1987). Analysis of genes involved in glucose repression and derepression in Saccharomyces cerevisiae. Foundation for Biotechnical and Industrial Fermentation Research 5, 75-89.

Gage, R. A., van Wijngaarden, W., Theuvenet, A. P. R., BorstPauWels, G. W. F. H. \& HaAsnoot, C. A. G. (1984). Localization and identification of the compound causing peak ' $\mathrm{X}$ ' in the ${ }^{31} \mathrm{P}$ NMR spectrum of Saccharomyces cerevisiae. Biochimica et Biophysica Acta 804, 341-347.

GANCEDO, J. M. \& GANCEDO, C. (1986). Catabolite repression of yeast. FEMS Microbiology Reviews 32, 179-187.

Gillies, R. J., Alger, J. R., Den Hollander, J. A. \& Shulman, R. G. (1982). Intracellular $\mathrm{pH}$ measured by NMR: methods and results. In: Intracellular pH: Its Measurement, Regulation and Utilization in Cellular Functions, pp. 79-104. New York: Alan R. Liss.

Loureiro-Dias, M. C. \& Peinado, J. M. (1984). Transport of maltose in Saccharomyces cerevisiae. Effect of $\mathrm{pH}$ and potassium ions. Biochemical Journal 222, 293-298.

Navon, G., Shulman, R. G., Yamane, T., Eccleshal, T. R., Lam, K.-B., BaronofsKy, J. J. \& MARMUR, J. (1979). Phosphorus-31 nuclear magnetic resonance studies of wild-type and glycolytic pathway mutants of Saccharomyces cerevisiae. Biochemistry 18, 44874489.

NIEDERACHER, D. \& ENTIAN, K.-D. (1985). Isolation and characterization of the regulatory $H E X 2$ gene necessary for glucose repression in yeast. Molecular and General Genetics 206, 505-509.

ROTTENBERG, H. (1979). The measurement of membrane potential and $\Delta \mathrm{pH}$ in cells, organelles and vesicles. Methods in Enzymology 55, 547-569.

SANTOS, H. \& TURNER, D. L. (1986). Characterization of the improved sensitivity obtained using a flow method for oxygenating and mixing cell suspensions in NMR. Journal of Magnetic Resonance 68, 345349.

SERRANo, R. (1977). Energy requirements for maltose transport in yeast. European Journal of Biochemistry 80, 97-102.

ZAMENHOFF, S. (1957). Preparation and assay of deoxyribonucleic acid from animal tissue. Methods in Enzymology 3, 696-704.

ZimmermanN, F. K., Khan, N. A. \& Eaton, N. R. (1973). Identification of new genes involved in disaccharide fermentation in yeast. Molecular and General Genetics 123, 29-41.

ZimmermanN, F. K. \& SCHEel, I. (1977). Mutants of Saccharomyces cerevisiae resistant to carbon catabolite repression. Molecular and General Genetics 154, 75-82. 